Instructions/Template for Preparing Manuscript for Jendela Nursing Journal

\title{
Developments in Electronic Nursing Logbooks in Health Service Areas: Literatur Review
}

\author{
Tsania Ayu Zaharany ${ }^{1}$, Rr. Tutik Sri Hariyati ${ }^{1}$ \\ ${ }^{1}$ Nursing Department, Universitas Indonesia \\ Corresponding author: tsaayu1903@gmail.com
}

\begin{abstract}
Background: Efforts to reduce the impact of the logbook vacancy and facilitate nurses in documentation in the industry 4.0 era have been developed with electronic logbooks (E-logbooks) used for more accurate documentation and assessing performance based on the achievement of individual utility activities. . The electronic logbook (E-logbook) of nurses is designed to be a documentation that records the achievement of activities, nurses' skills, and updates all activities, such as Continuous Professional Development (CPD), and is used in assessing employee behavior for 1 (one) year .

Purpose: Make a summary and analysis of articles related to the nurse's Electronic logbook (E-logbook).

Methods: Literature review is done by making a summary and analysis of the article. The method of searching articles in the literature review uses several electronic databases, namely Google Scholar, PubMed, JHA Science Direct, CINAHL, and ProQuest with the keywords electronic logbook nursing. The impact of the Elcetronic logbook on individual performance assessments that reflect staff competencies and performance and is carried out objectively and transparently so that the potential also increases the motivation of clinical staff which can lead to increased productivity and quality of health service.

Results: Nurse e-Logbook has an important role, namely as evidence of documentation of the implementation of activities and clinical supervision.

Conclusion: In Indonesia, only a small portion of health services, which already uses an electronic logbook program.
\end{abstract}

\section{Keywords:}

Elcetronic Logbook; Nurses; Quality; Health Services.

\section{LATAR BELAKANG}

Era revolusi industry 4,0 kehidupan manusia sudah mengalami perubahan dalam hal teknologi. Segala hal menjadi tanpa batas akibat perkembangan dari teknologi digital dan internet. Hal tersebut telah mempengaruhi askpek positif dalam bidang kesehatan yaitu persaingan rumah sakit dalam pelayanan kesehatan. Saat ini persaingan antara rumah sakit telah menyebabkan adanya pergeseran tuntuan dalam pelayanan kesehatan 
sehingga rumah sakit harus memberikan upaya kesehatan yang komperhensif. Klien selain menginginkan kesembuhan, juga menuntut dalam kenyamanan pelayanan yang mereka terima sehingga rumah sakit mengupayakan pelayanan yang berkualitas dan bermutu bagi klien dan keluarga. Dampak dari pelayanan rumah sakit yang bermutu akan meningkatkan kredibilitas rumah sakit di masyarakat (Robbins, Stephen P. \& Judge, 2016).

Kualitas pelayanan kesehatan yang bermutu tentu didukung dari kinerja staf yang kompeten dan manajemen yang baik. Standar Nasional Akreditasi Rumah Sakit (SNARS) Edisi 1 pada KKS 6 menunjukkan setiap rumah sakit mempunyai dokumen catatan yang memuat informasi terkait kualifikasi, pendidikan,kompetensi, uraian tugas, hasil evaluasi, dan penilaian individual yang terstandar dan diperbaharui sesuai dengan regulasi. Salah satu standar pengukuran IKI (indikator kinerja individu ) di rumah sakit yaitu staf klinis meliputi staf medis, staf keperawatan, dan staf klinis lainnya. (KARS, 2017). Penilaian indikator kinerja individu (IKI) merupakan salah satu dari jenis penilaian indikator mutu. Salah satu penilaian indikator kinerja individu pada bidang keperawatan dapat dilihat dari logbook keperawatan (Robbins, Stephen P. \& Judge, 2016).

Logbook perawat memiliki peranan penting yaitu sebagai bukti dokumentasi pelaksanaan kegiatan dan supervisi klinis. Logbook merupakan salah satu cara yang digunakan oleh komite keperawatan dalam memastikan perawat telah kompeten melaksanakan kewenangan klinis yang diberikan kepadanya. Kegunaan logbook perawat sebagai alat monitoring dan evaluasi pelaksanaan kompetensi klinis, selain itu digunakan sebagai alat pertanggungjawaban perawat terhadap penugasan klinis yang telah diberikan (PMK no. 49, 2013; Kemenkes, 2013). Logbook juga dimanfaakan sebagai salah satu strategi pencegahan penilaian kinerja yang bias.

Kekosongan logbook keperawatan sudah sangat sering terjadi di pelayanan kesehatan. Hal tersebut di buktikan dengan data yang diambil pada bulan Januari 2016 jumlah perawat yang telah dilakukan kredensial sebanyak 456 perawat $(32,88 \%)$, sehingga $67,12 \%$ perawat belum mengikuti proses kredensial (Komsiyah, Indarti, 2019). Berdasarkan data tersebut di dukung penelitian dari Yahya, tahun 2019 menunjukkan bahwa faktor yang menjadi penghambat perawat dalam pengisian manual logbook antara lain pengetahuan perawat, kecapean, kesibukan, kurangnya semangat diri, tidak adanya feedback dari pimpinan, logbook tidak mudah dalam mengisinya, serta belum adanya reward khusus logbook. Menurut Cern \& Athena juga menyampaikan bahwa kekurangan dari logbook manual yaitu membutuhkan waktu yang lama dalam mengisis sehingga akan tidak bias mengisi setiap harinya dan apabila proses penulisanya yang terburu-buru akan mempersulit pemahaman di waktu yang akan datang (Cern \& Athena, 2006).

Dampak dalam kekosongan dan ketidakjelasan tulisan akan menimbulkan masalah pendokumentasian dan penilaian. Penilaian akan bersifat subyektif karena bias dan juga belum mencerminkan kewenangan klinis setiap profesi disebakan kurangnya kompetensi. Disparitas dan ketidakmampuan membedakan tingkat aktivitas individu ini juga berpotensi terhadap ketidakpuasan serta ketidakpercayaan staf klinis pada sistem penilaian kinerja individunya sehingga muncul prasangka. Berpotensi pula terjadi 
Jendela Nursing Journal, 4(1), 2020,

demotivasi staf klinis yang dapat mengakibatkan penurunan produktivitas dan $\mathrm{n} 40$ layanan kesehatan (Yahya, 2019).

Upaya dalam mengurangi dampak kekosogan logbook serta memudahkan keperawatan dalam dokumentasi pada era industry 4.0 telah dikembangan elcetronic logbook ( $E$ logbook) yang dapat digunakan untuk dokumentasi lebih akurat dan menilai kinerja berbasis pencapaian utilitas aktivitas secara individu. E-logbook terus dikembangkan untuk mempermudah dalam pencatatan secara kuantitatif aktivitas setiap staf klinis sesuai dengan rincian kewenangan klinis. E-logbook perawat dirancang menjadi sebuah dokumentasi yang berisi catatan pencapaian keterampilan-keterampilan perawat dan memperbaharui apapun kegiatan, seperti Continous Professional Development (CPD), serta digunakan dalam melakukan penilaian terhadap perilaku pegawai selama 1 (satu) tahun (Komsiyah, Indarti (2019).

\section{METODE}

Metode literature review dilakukan dengan membuat ringkasan dan analisis dari artikel yang terkait dengan pertanyaan dan tujuan penelitian. Metode pencarian artikel dalam literatur review menggunakan beberapa database elektronik, yakni Google Scholar, PubMed, JHA Science Direct, CINAHL, dan ProQuest dengan kata kunci electronic logbook nursing, electronic logbook perawat, advantage E-logbook system, limitation E-logbook, dan Implementation electronic logbook nursing. Kriteria inklusi: 1) artikel yang memiliki judul dan isi yang relevan dengan tujuan penelitian; 2) berbahasa Inggris dan berbahasa indonesia fulltext; 3) artikel penelitian minimal kohort yang dipublikasi pada 2014-2019. Kriteria eksklusi: 1) tidak memiliki struktur artikel yang lengkap; 2) review artikel

\section{HASIL}

Era revolusi industry 4.0 sudah mengalami perubahan serba digital termasuk bentuk logbook yang semula manual menjadi elektronik. Jenis manual logbook bisa bermacam-macam seperti buku, catatan, lembaran kertas dan lain- lain. Elektronik logbook juga beraneka bentuk seperti komputerisasi, program pada website, perangkat lunak dan aplikasi pada IOS atau Android. Logbook dilihat dari penampilanya terbagi menjadi dua yaitu tampilan landscape, portrait, virtual dengan kreasi yang menitik beratkan kemudahan, kesederhanaan, dan estetika. Elcetronic logbook dapat digunakan di area manapun termasuk area pelayanan keperawatan (Schüttpelz-Brauns et al., 2016).

Program electronic logbook sudah digunakan di Indonesia meski hanya sebagian kecil di area pelayanan kesehatan. Penelitian ini menunjukkan untuk memperkuat dan mendukung program electronic logbook yang tersedia dengan memberikan informasi secara besar-besaran atau sosialisasi sehingga semua perawat dapat mengambil manfaat dari program ini. Setiap rumah sakit memiliki hambatan dalam elektronik logbook diantaranya pada aspek sumber daya manusia, fasilitas, dan infrastruktur masih belum memadai, meskipun begitu tidak menjadi halangan untuk menerapkan pengunaan electronic logbook di dalam pelayanan kesehatan. Pengunaan electronic logbook di area global kebanyakan digunakan pada area pendidikan dan penelitian keperawatan (Cevik,Shaban, El Zubeir, \& Abu-Zidan, 2018). Dua jurnal yang membahas terkait Elogbook di dunia pendidikan dan dua jurnal yang membahas E-logbook yang digunakan dalam penelitian perawat. 
E-logbook mampu mengatasi permasalahan di area pendidikan keperawatan terkait penumpukan evaluasi pada akhir semester. Pengajar pada saat menggunakan E-logbook bisa mengakses kapanpun dan dimanapun sehingga bisa memantau kinerja mahasiswa dan memberikan umpan balik secara langsung (Cevik, Shaban, El Zubeir, \& Abu-Zidan, 2018). Pemantauan dan analisis E-logbook yang tepat dapat mengubah kegiatan mengajar dan belajar serta memberikan panduan untuk modifikasi kurikulum di masa mendatang sehingga meningkatkan mutu keperawatan (Fatemeh \& Alavinia, 2014).

Tujuh jurnal yang membahas terkait E-Logbook menujukkan hasil penelitian bahwa $E$ Logbook perawat memiliki peranan penting yaitu sebagai bukti dokumentasi pelaksanaan kegiatan dan supervisi klinis. E-Logbook merupakan salah satu cara yang digunakan oleh komite keperawatan dalam memastikan perawat telah kompeten melaksanakan kewenangan klinis yang diberikan kepadanya (Yahya,2019). Kegunaan E-logbook perawat sebagai alat monitoring dan evaluasi pelaksanaan kompetensi klinis, selain itu digunakan sebagai alat pertanggungjawaban perawat terhadap penugasan klinis yang telah diberikan. Hal tersebut harus sesuai dengan PMK no. 49, 2013; Kemenkes, 2013. Penilaian prestasi kerja merupakan sebuah proses formal dalam melakukan peninjauan ulang dan evaluasi prestasi kerja seseorang secara periodik. Suatu rancangan yang obyektif, terukur, akuntabel, partisipasi serta transparan kepada penilaian prestasi sehingga dapat menjadi alat yang berguna bagi organisasi (Purnawati, F, 2015).

E-Logbook juga dimanfaakan sebagai salah satu strategi pencegahan penilaian kinerja yang bias (Robbins, Stephen P. \& Judge, 2016). Salah satu teknik organisasi dapat mempertimbangkan untuk meningkatkan proses penilaian kinerja dengan posting penilaian online sehingga karyawan dapat melihat Skor kinerja mereka sendiri tepatnya (Nesit, L, Paul, 2017). Salah satu strategi lainnya yang digunakan dalam hal terseut mendokumentasikan perilaku kinerja dalam E-Logbook. Penelitian lain juga menujukkan bahwa salah satu strategi dalam meminimalisir bias dengan penilaian kinerja secara terbuka. Salah satu dokumentasi perilaku kinerja dalam penelitian ini menggunakan metode E-Logbook (Spence J,R dan Keeping, 2011).

E-logbook terus dikembangkan untuk mempermudah dalam pencatatan secara kuantitatif aktivitas setiap staf klinis sesuai dengan rincian kewenangan klinis. $E$ logbook)dapat digunakan pada perawat untuk dokumentasi lebih akurat dan menilai kinerja berbasis pencapaian aktivitas yang bermanfaat secara individu (Shayan, Mosavi, \& Yousefy, 2012). E-logbook perawat dirancang menjadi sebuah dokumentasi yang berisi catatan pencapaian aktivitas, ketrampilan-ketrampilan perawat, dan memperbarui secara otomatis semua kegiatan, seperti Continous Professional Development (CPD), serta digunakan dalam melakukan penilaian terhadap perilaku pegawai selama 1 (satu) tahun (Komsiyah, Indarti, 2019).

\section{PEMBAHASAN}

Perkembangan elektronik logbook dalam dunia keperawatan mengalami berbagai perubahan dalam bentuk maupun tampilan sesuai dengan revolusi industry 4.0 era digital. Penerapan era digital ini mengembangkan logbook menjadi E-logbook sehingga memudahkan perawat dalam mempermudah pekerjaan di area pelayanan, perawat pengajar, penelitian, dan mahasiswa praktik dengan hasil akhir meningkatkan mutu 
keperawatan sesuai standar keperawatan. Area pelayanan dalam meningkatkan keselamatan dan kepuasaan pasien tentu dimbangi dengan cara meningkatkan kinerja yang baik beriringan dengan mutu pelayanan semakin meningkat.

Penelitian Yahya tahun 2019 di rumah sakit Cirebon menunjukkan bahwa pengembangan E-Logbook memungkinkan semua aktivitas staf klinis tercatat pada tingkat individu, sehingga penilaian kinerjanya dilakukan secara akurat. Proses input data pada menu tindakan dalam E-Logbook harus diisi semua aktivitas oleh staf klinis sesuai dengan kewenangan klinis dan kompetensi yang dimilikinya. Pelaporan pada staf klinis dapat dilihat dari sistem secara online, hal ini akan memacu staf klinis lebih tertib dan disiplin dalam menginput data. Setiap saat supervisor dapat mengetahui aktivitas dan pencapaian kinerjanya sehingga dapat membandingkan hasil dengan target yang harus dicapai untuk memenuhi kompetensi, target utilisasi, dan revenue yang telah ditetapkan rumah sakit. E-Logbook dapat diakses oleh staf klinis melalui applikasi smartphone dan website secara online.

Penelitian Ullah tahun 2019 juga mendukung terkait E-logbook atau E-log system yang menjelaskan terkait catatan harian yang dimasukan perawat kepada menu tindakan pada saat proses input data, setelah input data berhasil di lakukan perawat maka data tersedia untuk Supervisor. Setiap saat supervisor dapat mengetahui aktivitas dan pencapaian kinerjanya perawat klinis. Supervisor mampu memberikan umpan balik terstruktur pada perawat sesuai dengan standar. E-logbook sangat baik digunakan untuk dokumentasi dan menganalisa data terkait kegiatan klinis dalam keseharian perawat. E-logbook perawat digunakan sebagai alat monitoring dan evaluasi pelaksanaan kompetensi klinis. E-logbook tersebut mulai digunakan untuk menambah kenyamanan dan fleksibilitas tenaga kesehagatan (Ullah et al., 2019).

Penelitian Purnawati, tahun 2015 pada perawat PNS menujukkan dengan computerisasi sederhana E-logbook perawat digunakan sebagai alat monitoring dan evaluasi pelaksanaan kompetensi klinis, selain itu digunakan sebagai alat pertanggungjawaban perawat terhadap penugasan klinis yang telah diberikan juga sebagai evaluasi presetasi kerja individu secara periodik. Hal tersebut harus sesuai dengan PMK no. 49 tahun 2013. Penilaian prestasi kerja merupakan sebuah proses formal dalam melakukan peninjauan ulang dan evaluasi prestasi kerja seseorang secara periodik. Proses penilaian prestasi kinerja perawat di dukungn dengan data penujang yang ada di logbook. Penilaian prestasi kerja yang obyektif, terukur, akuntabel, partisipasi serta transparan dapat menjadi alat yang berguna bagi organisasi dapat terbukti dengan melihat $E$ logbook. E-logbook akan di input perawat selama 1 (satu) tahun maka secara otomatis pengukuran SKP sekaligus penilaian prestasi kerja pegawai dapat diselesaikan dengan lebih mudah dan cepat.

Penilaian kinerja individu seharusnya mencerminkan kompetensi dan kinerja staf serta dilaksanakan secara obyektif dan transparan sehingga dapat meningkatkan motivasi kerja. Bila hal ini tidak dilaksanakan maka potensi ketidakpuasan dan penurunan motivasi serta kinerja staff dapat terjadi. Disamping itu pencapaian kinerja individu akan berpengaruh terhadap pencapaian kinerja di rumah sakit. Kebutuhan akan transparasi saat evaluasi sangat banyak didukung oleh staf klinis dengan salah satu cara melalui program digital. Hal tersebut dikarenakan pada program digital mampu diakses 
oleh semua staf dan supervisor sehingga lebih obyektif (Robbins, Stephen P. \& Judge, 2016). Penelitian Nesit tahun 2017 salah satu teknik organisasi dapat mempertimbangkan untuk meningkatkan proses penilaian kinerja dengan posting penilaian online sehingga karyawan dapat melihat skor kinerja mereka sendiri. Hal ini di nilai lebih terbuka karena system menampilkan segala aspek (Nesit, L, Paul, 2017).

Salah satu strategi lainnya yang digunakan dalam mendokumentasikan perilaku kinerja dengan menggunakan E-Logbook. Penelitian lain juga menujukkan bahwa salah satu strategi dalam meminimalisir bias dengan penilaian kinerja secara terbuka. Salah satu dokumentasi perilaku kinerja dalam penelitian ini menggunakan metode E-Logbook. Metode E-Logbook digunakan perawat sebagai alat monitoring dan evaluasi pelaksanaan kompetensi klinis, selain itu digunakan sebagai alat pertanggungjawaban perawat terhadap penugasan klinis yang telah diberikan juga sebagai evaluasi penilaian kinerja individu secara periodik. (Spence J,R dan Keeping, 2014). Perbandingan manual logbook dengan E-logbook mempunyai kelebihan dan kelemahan masingmasing. Pada penelitian mengatakan bahwa kelebihan digital ini dalam menginput catatan aktivitas dan mengumpulkan data lebih jelas serta mudah dibawa kapanpun dan dimanapun tanpa batas. Hal tersebut didukung dengan adanya sistem PDA (personel digital assistant). Dalam kelemahanya dijelaskan juga terdapat teknis dari E-logbook dan terbatasnya penguna dalam aplikasi digital (Shayan, Mosavi, \& Yousefy, 2012).

Manfaat E-logbook di tunjukkan pada penelitian Cevik tahun 2018 bahwa mengumpulkan, mengevaluasi, dan menganalisis manual logbook di akhir yudisium sulit dilakukan dan tidak berguna untuk melakukan umpan balik. E-logbook mampu mengatasi permasalahan terkait penumpukan evaluasi di akhir. Pengajar pada saat menggunakan E-logbook bisa mengakses sehingga bisa memantau mahasiswa dalam kinerjanya dan memberikan umpan balik. Pemantauan dan analisis E-logbook yang tepat dapat mengubah kegiatan mengajar dan belajar serta memberikan panduan untuk modifikasi kurikulum di masa mendatang (Cevik, Shaban, El Zubeir, \& Abu-Zidan, 2018). Peneleitian yang di lakukan Fatemeh tahun 2014 ini di area pendidikan saat mahasiswa melakukan praktek klinik. Berdasarkan beberapa penelitian seperti jurnal mendukung adanya E-logbook pada area pendidikan dan penelitian. E-logbook sudah dimanfaatkan di area pelayanan, pendidikan hinngga penelitian dengan persamaan fungsi dokumentasi, pelaporan dan evaluasi kinerja (Fatemeh \& Alavinia, 2014).

Berdasarkan telah 10 artikel dapat disimpulkan bahwa dampak dari Electtronic logbook pada penilaian kinerja individu yang mencerminkan kompetensi dan kinerja perawat serta dilaksanakan secara obyektif dan transparan sehingga berpotensi pula meningkatkan motivasi perawat klinis yang dapat mengakibatkan peningkatan produktivitas dan mutu layanan kesehatan Berdasarkan beberapa penelitian diatas mendukung adanya E-logbook pada area pendidikan dan penelitian. E-logbook sudah dimanfaatkan di area pelayanan, pendidikan hingga penelitian dengan persamaan fungsi dokumentasi, pelaporan dan evaluasi kinerja.

\section{SIMPULAN}

Elcetronic logbook (E-logbook) yang dapat digunakan pada perawat untuk dokumentasi lebih akurat dan menilai kinerja berbasis pencapaian aktivitas secara individu. Elogbook terus dikembangkan untuk mempermudah dalam pencatatan secara kuantitatif 
aktivitas setiap staf klinis sesuai dengan rincian kewenangan klinis. E-logbook perawat dirancang menjadi sebuah dokumentasi yang berisi catatan pencapaian aktivitas dan keterampilan-keterampilan perawat serta memperbarui secara otomatis semua kegiatan, seperti Continous Professional Development (CPD). E-logbook digunakan dalam melakukan penilaian terhadap perilaku pegawai selama 1 (satu) tahun. Dampak dari Elctrotronic logbook pada penilaian kinerja individu yang mencerminkan kompetensi dan kinerja staf serta dilaksanakan secara obyektif dan transparan sehingga berpotensi pula meningkatkan motivasi staf klinis yang dapat meningkatkan produktivitas dan mutu layanan kesehatan.

Di Indonesia hanya sebagian kecil pelayanan kesehatan, yang sudah menggunakan program electronic logbook. Program Elcetronic logbook dapat digunakan pada perawat untuk dokumentasi lebih akurat dan menilai kinerja berbasis pencapaian aktivitas secara individu Penelitian ini menunjukkan untuk memperkuat dan mendukung program electronic logbook yang tersedia dengan memberikan informasi secara besar-besaran tentang program ini melalui sosialisasi sehingga semua perawat dapat mengambil manfaat dari program ini. Meskipun di beberapa rumah sakit tertentu sumber daya manusia, fasilitas, dan infrastruktur masih belum memadai, meskipun begitu tidak menjadi halangan untuk menerapkan pengunaan electronic logbook di dalam pelayanan kesehatan.

Implikasi studi ini menunjukkan bahwa adanya dampak positif terhadap pengunaan electronic logbook pada staf klinis. Hal ini mengandung implikasi agar kedepanya perekembangan era digital akan semakin maju dengan adanya electronic digital akan semakin berkembang sehingga mutu pelayanan akan semakin meningkat.

\section{REFERENSI}

Cevik, A. A., Shaban, S., El Zubeir, M., \& Abu-Zidan, F. M. (2018). The role of emergency medicine clerkship e-Portfolio to monitor the learning experience of students in different settings: a prospective cohort study. International Journal of Emergency Medicine, 11(1). https://doi.org/10.1186/s12245-0180184-9

Fatemeh, K., \& Alavinia, S. M. (2014). Students' perception about logbooks: Advantages, limitation and recommendation - A qualitative study. Journal of the Pakistan Medical Association, 62(11), 1184-1186.

Spence J,R and Keeping. (2014). Conscious Rating Distortion in Performance Appraisal: A Review, Commentary, and Proposed Frame-work for Research," Human Resource Manage- ment Review 21 (2).85-95

Nesit, L, Paul. (2017) . Improving confidence and accuracy in performance apprasials. Journal of the Australian and New Zealand Academy Managemnt. 8(2). 40-42 PMK no 49 Tahun 2013 Tentang Komite Keperawatan.

Robbins, Stephen P. \& Judge, T. A. (2016). Organizattional Behabiour. 1-747.

Shayan, S., Mosavi, A., \& Yousefy, A. (2012). Developing a clinical performance logbook for nursing students receiving cardiac care field training. Journal of Education and Health Promotion, 1(1), 7. https://doi.org/10.4103/22779531.94415

Yahya, A. (2019). Praktik Peningkatan Mutu. 01, 18-23. 